\title{
Association of plasma DNA integrity and long fragment ALU247 in the diagnosis of epithelial ovarian cancer
}

\author{
Feryal Farouk Sherif ${ }^{*}$, Mohamed Ali El Desouky ${ }^{b}$, Mona Gebrila $^{a}$ Osama Mahmoud Azmy ${ }^{a}$ \\ ${ }^{a}$ Department of Reproductive Health, Medical Research Division, National Research Centre, El-Bohouth Street, Dokki 12311, Giza, \\ Egypt \\ ${ }^{b}$ Department of Chemistry Research, Faculty of Science, Cairo University, 1 Gamaa Street, Giza 12613, Egypt
}

Received 1st March 2021 / Accepted 26th May 2021

\begin{abstract}
DNA Integrity index (DNA Int) and cell-free DNA (cf-DNA) represent promising biomarkers for epithelial ovarian cancer (EOC) detection. Tumor necrosis produces DNA fractions of different sizes, which contrasts apoptosis in normal tissue that releases smaller and more regular DNA fragments. Using ALU gene primers in quantitative PCR, the amplified cf-DNA is supposed to be either short fragments of $115 \mathrm{bp}$ (ALU 115) or long fragments of $247 \mathrm{bp}$ (ALU 247). ALU levels and DNA Int were determined in the plasma of 30 EOC patients, 30 benign cysts, and 15 healthy individuals. The mean values of DNA Int, ALU115, and ALU247 were elevated in malignant patients $(0.51 \pm 0.09,3.93 \mathrm{ng} / \mathrm{ul} \pm 1.93,2.35 \mathrm{ng} / \mathrm{ul}$ $\pm 1.1)$ respectively in comparison to healthy females $(0.37 \pm 0.05 ; \mathrm{p}<0.001,2.56 \mathrm{ng} / \mathrm{ul} \pm 0.9 ; \mathrm{p}=0.027$, $1.26 \pm 0.44 ; \mathrm{p}<0.01)$. A significant increase was shown in the mean values of DNA Int and ALU247 of EOC patients compared to those with benign cysts $(0.4 \pm 0.06, \mathrm{p}<0.001 ; 1.69 \pm 0.66, \mathrm{p}=0.008)$ respectively. The area under the curve (AUC) for EOC versus healthy females achieved 0.913 (DNA Int), 0.696 (ALU115), and 0.809 (ALU247) with sensitivities and specificities were (86.7\% and $93.3 \%$ ) for DNA Int, $(63.3 \%$ and $86.7 \%)$ for ALU115 and $(76.7 \%$ and $86.7 \%)$ for ALU247 respectively. Furthermore, comparing patients with EOC versus those with benign cysts gave AUC of 0.834 (DNA Int), 0.564 (ALU115), and 0.681 (ALU247) with sensitivities and specificities were (80\% and $80 \%$ ) for DNA Int, $(63.3 \%$ and $60 \%)$ for ALU115 and (60\% and 80\%) for ALU247 respectively. Higher DNA Int and plasma ALU247 could help in the assessment of EOC, and their measurements seem to have clinical value in diagnosis.
\end{abstract}

Keywords: DNA Integrity index; ALU115; ALU247 and ovarian cancer

\section{INTRODUCTION}

Epithelial ovarian cancer (EOC) is the most abundant type of ovarian tumor and occurs in around nine out of every ten cases of malignancy in the ovary. EOC is a preeminently leading agent of cancer-related death among women (Bray et al., 2018). The miserable outcomes are strongly associated with the high abundance of above $70 \%$ of EOC and are detected at late stages in which transperitoneal, hematogeneous, and lymphatic dissemination happened (Gasparri et al., 2016). Effective therapy can reach $90 \%$ at the early diagnosis of EOC when the tumor is yet pent to the ovary; the overall 5-year survival rate among these patients is about $70 \%$ (Schmalfeldt et al., 1995). Several attempts took place to enhance survival rates via early cancer diagnosing using transvaginal ultrasound and serum cancer antigen

*Author for correspondence: Feryal Farouk Sherif, Department of Reproductive Health, Medical Research Division, National Research Centre, El-Bohouth Street, Dokki 12311, Giza, Egypt. Email feryal_fk@aucegypt.edu 
125 (CA125) test (Buys et al., 2011; Jacobs et al., 2016).

Nevertheless, these approaches do not fulfill the clinical requirements for early diagnosis. Otherwise, CA125 would rise in other noncancerous diseases i.e., endometriosis and pelvic inflammatory (Moss et al., 2013). While CA125 levels exhibit high overlap in various diseases, a perceptible alternative is a cornerstone for timely discovery and prognosis.

Over the past few years have seen a renewed importance of tumor-related cf-DNA as a candidate biomarker for cancer diagnosis and prognosis. However, cf-DNA was potentially elevated in patients with different benign diseases such as autoimmune diseases, trauma, stroke, burns, and sepsis, therefore limiting its value for discrimination and diagnosis of cancer (Chiu et al., 2006; Lam et al., 2003; Rainer et al., 2003; Kakitsuka et al., 2020).

Previous reports were demonstrated that the DNA Int, calculated as the proportion of long to short DNA fractions, had greater values in patients with gynecologic malignancy than in healthy volunteers (Wang et al., 2003). Normal dead cells produce DNA fragments that are usually less than 185 to 200 (bp) in length (Giacona et al., 1998); these regularly, DNA fractions are released by a DNA-degrading enzyme during apoptosis. The apoptotic cell is the primary source of cf-DNA in healthy persons. In contrast, DNA produced from malignant cells are of a wide range in size due to cancer cells undergo different types of cell death, including necrosis, autophagy, or mitotic catastrophe (Jin and ElDeiry, 2005). Subsequently, a high concentration of non-apoptotic DNA is potentially an adequate marker for cancer diagnosis (Jahr et al., 2001; Stotzer et al., 2014).

Plasma was believed to be a preferable provenance of cf-DNA than serum. Some studies reported that the release of WBC's DNA in serum during the coagulation process could affect the DNA level in serum and thus be involved in the nonspecific elevation of DNA and higher variability (Wang et al., 2012; Zhong et al., 2007; Markus et al., 2018).

In this study, we used the ALU115 and ALU247 repeated DNA sequences to measure the absolute levels of short and long DNA fragments respectively by real-time PCR in the plasma of patients with EOC, benign cysts, and healthy females. Standard curves were generated to calculate the absolute levels of templates while DNA Int was calculated according to Wang et al., approach.

\section{MATERIALS AND METHODS}

\section{Subjects}

90 females with adnexal mass were followed up from June 2016 till November 2018 at Gynecology Departments, Kasr El Aini. The study was agreed by the Institutional Review Board (IRB), National Research Centre (NRC). Thirty patients proved to have EOC were selected to enter the study in addition to 30 females with benign cysts and 15 healthy volunteers' females.

Preoperative patients with primary EOC and benign cysts were assessed clinically by imaging and serum CA125 level and finally pathologically affirmed after surgery. Cancer staging Figo (I-III) was based on postoperative histopathology findings. Patients selected for study purposes were examined to be free from diabetes mellitus, hypertension, chronic liver and heart diseases, and autoimmune disorders; such conditions can affect the cf-DNA level. Before any therapeutic intervention, blood samples were obtained from all participants and transferred to the Medical Research Center of Excellence (MRCE), National Research Centre (NRC). Before the beginning of the study, written informed consent was taken from all participants.

\section{Samples preparation}

$5 \mathrm{ml}$ peripheral blood samples were collected in K2-EDTA (Sarstedt, Nürnbrecht, Germany). As well as $3 \mathrm{ml}$ of blood was withdrawn to test serum CA125. After blood sample collection, plasma was separated and centrifuged within $2 \mathrm{hrs}$ at $4000 \times \mathrm{g}$ for $15 \mathrm{mins}$ at $4^{\circ} \mathrm{C}$. The supernatant was taken with care and centrifuged twice at $14,000 \times \mathrm{g}$ for 5 mins at $4^{\circ} \mathrm{C}$ to avoid contamination with nucleic acids from cell debris; separated plasma was aliquoted and stored at $-20^{\circ} \mathrm{C}$.

\section{DNA extraction}

DNA extraction was carried out using a QIAamp DNA Mini Kit (Qiagen, Germany) specified by 
the manufacturer's recommendations. At first, $200 \mu \mathrm{l}$ of plasma sample and $200 \mu \mathrm{l}$ of lysis buffer were added to $20 \mu$ l of Qiagen protease. Afterward, incubation was done for $30 \mathrm{~min}$ at $57^{\circ} \mathrm{C} ; 200 \mu \mathrm{l}$ of absolute ethanol was added into the mixtures and mixed gently. Later, the mixture was pipetted into the spin column and washed with 750 ul by two washing buffers. Afterward, the spin columns were centrifuged, and the eluent was discarded, $50 \mu \mathrm{l}$ of TE buffer was added, and centrifugation was performed to elute the DNA. Purified DNA was ultimately kept at $-80 \mathrm{C}$ until use.

\section{Real-time PCR of ALU elements}

Amplification of short and long ALU repeats was done using the primers pairs illustrated by (Umetani et al., 2006). The results obtained with the ALU115 primers represent total cfDNA quantity, while those of ALU247 primers reflect the amounts of DNA released from malignant tumors. The primers sequences were as following: ALU115 - forward, 5'-CCTGAGGTCAGGAG TTCGAG-3' and reverse, 5'-CCCGAGTAG CTGGGATTACA-3' ALU 247 - forward, 5'GTGGCTCACGCCTGTAATC-3' and reverse, 5'-CAGGCTGGAGTGCAGTGG-3

The reaction mixture of the RT-qPCR consisted of $1 \mu \mathrm{l}$ of template of cf-DNA, $1 \mu \mathrm{l}$ of 10 pmole from forward and reverse primers, $7 \mu \mathrm{l}$ of Nuclease free $\mathrm{H} 2 \mathrm{O}$, and $10 \mu \mathrm{l}$ of SensiFAST ${ }^{\mathrm{TM}}$ SYBR Lo-ROX (Bioline, USA), a total of $20 \mu \mathrm{l}$ reaction volume. Quantitative PCR was done using the ABI 7500 Fast cycler (Applied
Biosystems, Foster City, CA, USA). It initiated with 5 mins of activation time for the HotStart DNA Taq Polymerase at $95^{\circ} \mathrm{C}$. The qPCR amplification was done with 40 cycles of denaturation (at $95^{\circ} \mathrm{C}$ for $15 \mathrm{~s}$ ), annealing, and fluorescence data collection (at $65^{\circ} \mathrm{C}$ for $60 \mathrm{~s}$ ). A standard curve was created to measure the total quantity of DNA in each sample. Serial dilutions from 0.1 to $0.076 \mathrm{ng} / \mathrm{ul}$ of genomic DNA were applied (Applied Biosystem) in 5 dilution steps. The standard curve for ALU115 had an efficiency of 2.03; for ALU247, the efficiency was 1.91 (Figure 1). The melting curves showed ALU115 bp. and ALU247 bp peaks of about $87^{\circ} \mathrm{C}$ and $85^{\circ} \mathrm{C}$, respectively.

Furthermore, negative and positive control were added in every qPCR run for quality assurance. The experiment was conducted in a randomized and blinded manner.

\section{Data analysis}

DNA Integrity Index as a ratio of ALU247 to ALU115 was measured based on Wang et al., formula DNA Int $=\mathrm{e}(-\Delta \Delta \mathrm{Cp} \times \ln (2))$, the widely applied approach for measurement of DNA Integrity in cancer patients (Wang et al., 2003). Therein, the mean quantity of $\mathrm{Ct}$ value was calculated by qPCR software, $\Delta \Delta \mathrm{Cp}$ is the difference between $\Delta \mathrm{Cp}$ ALU115 and $\Delta \mathrm{Cp}$ ALU247, and $\Delta$ Cp- ALU 115 and $\Delta$ Cp ALU247 was calculated as the difference between the $\mathrm{Cp}$ value of a standard pool of genomic DNA and the Cp value of both ALU115 and ALU247.
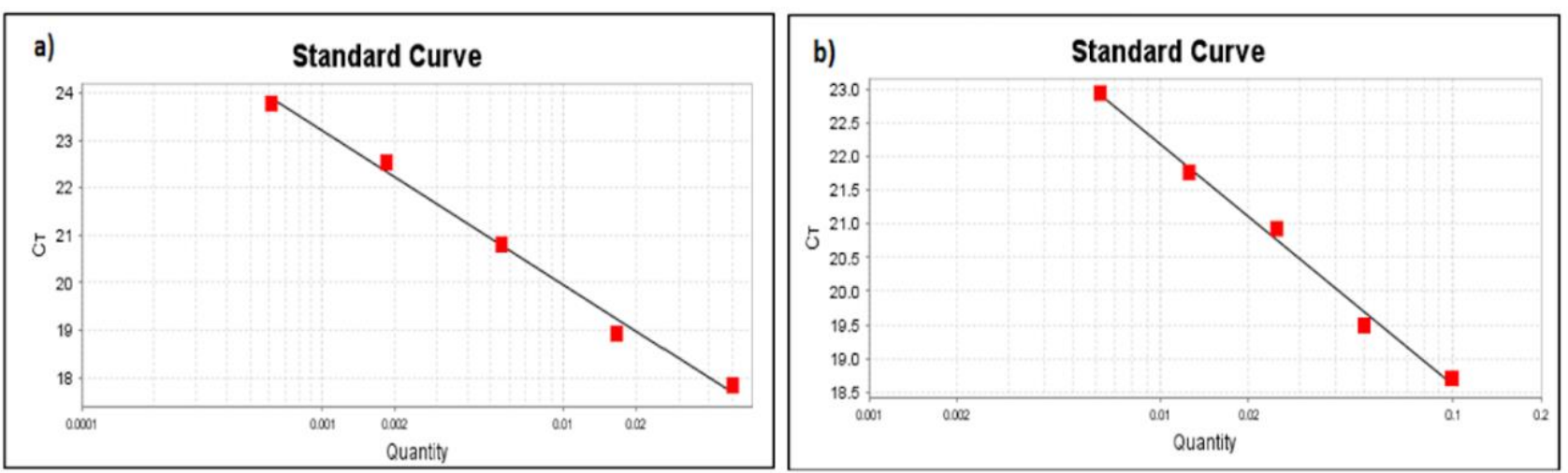

Figure 1. (a) and (b) Representative standard curves for ALU115 and ALU247, respectively, obtained by Q-PCR. For ALU115, amplification efficiency $=103.5 \%$, Slope $=-3.241$ and R2 $=0.994$. For ALU247, amplification efficiency $=91 \%$, Slope $=-3.5$ and $\mathrm{R} 2=0.993$. 

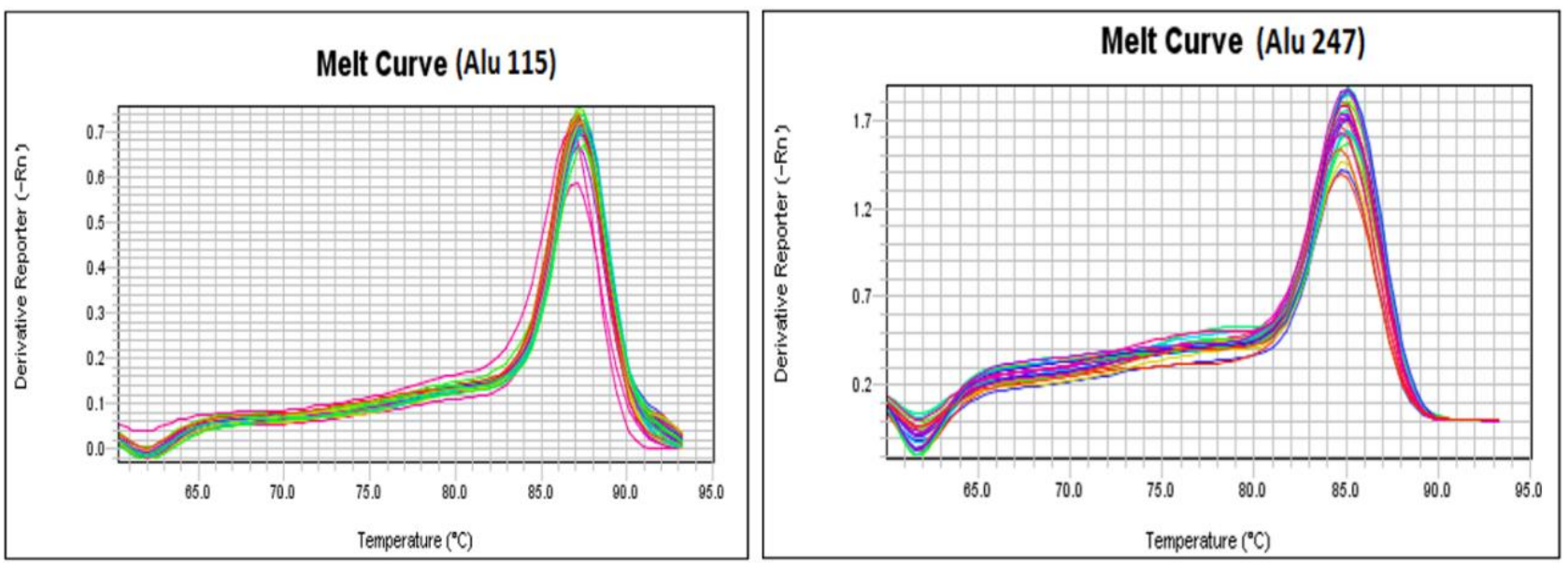

Figure 2. Melting curves of ALU 115bp and ALU 247bp amplifications. Following amplification, melting curves were achieved by calculating the derivatives $\mathrm{dF} / \mathrm{dT}$ vs. temperature. Amplified ALU115bp and ALU247bp generate peaks of about $87^{\circ}$ and $85^{\circ} \mathrm{C}$ respectively.

\section{Statistics methods}

The statistical analysis was done using SPSS software 22. The initial valuation indicated DNA Int, ALU115, and ALU247 were normally distributed. ANOVA test was applied to assess possible differences among average values of variables $(\mu)$ in cases of EOC, benign cysts, and healthy females. The mean values of Age and CA125 were not normally distributed among the different groups. Inter-group analysis was performed using Mann-Whitney $U$ test. ROC curve was applied to determine the cut-off value that would differentiate between the examined groups and calculate sensitivity and specificity. Spearman correlation test was applied to assess the association of serum CA125, ALU115, ALU247, and DNA Int with EOC. Two-tailed $\mathrm{P}<0.05$ was believed to be statistically significant.

\section{RESULTS}

\section{Clinical and pathology of epithelium ovarian cancer}

Clinical and pathological data of patients suffering from epithelial ovarian lesions, benign cysts, and healthy females are given in Table 1. Age did not show a significant difference among any groups. However, CA125 was discriminated significantly via Kruskal-Wallis $\mathrm{H}$ test. Further inter-group analysis by Mann-Whitney $U$ revealed a significant increase of CA125 level in EOC patients when compared to benign and healthy females Table 2 . DNA Int, ALU115, and ALU247 were normally distributed and represented as mean \pm standard deviation (SD). The mean level of DNA Integrity, ALU115, and ALU247 was discriminated significantly in patients with malignant lesions than those healthy volunteers estimated by ANOVA Table 3. Furthermore, the mean level of DNA Integrity and ALU247 increased in malignant patients than those with benign cysts with significant differences. In contrast, ALU115 did not show differences between the same groups. No significant differences were encountered among benign and healthy groups in terms of age, CA125, ALU115, ALU247, and DNA Int $(\mathrm{P}>0.05)$ Figure 3.

\section{Associations of plasma ALU115, ALU247, and DNA Int with CA125 in EOC}

Respect to Spearman correlation coefficient, no associations between plasma ALU115, ALU247, and DNA Int with serum CA125 were detected $(\mathrm{r}$ $=0.07, \mathrm{P}=0.71 ; \mathrm{r}=0.102, \mathrm{P}=0.594 ; \mathrm{r}=0.02, \mathrm{P}$ $=0.274$; respectively).

Diagnostic utility of DNA Integrity index, plasma ALU concentration, and serum CA125 ROC curve analysis was used to assess the performance of ALU115, ALU247, DNA Int, and CA125 in the diagnosis of malignant disease as shown in Figure 4. Comparison of EOC with healthy females gave AUC 0.91 for (DNA Int), 0.696 (ALU115), 0.809 (ALU247), and 0.892 
(CA125). Sensitivity and specificity for cancer detection were $86.7 \%$ and $93.3 \%$ for (DNA Int), $60 \%$ and $80 \%$ (ALU115), $76.7 \%$ and $80 \%$ (ALU247) and $70 \%$ and $89.2 \%$ (CA125) respectively. For a comparison of EOC with the benign group, AUC achieved 0.83 (DNA Int),
0.564 (ALU115), 0.681 (ALU247), and 0.816 (CA125). Sensitivity and specificity were $80 \%$ and 80\% (DNA Int), 63.3\% and 60\% (ALU115), 60\% and $80 \%$ (ALU247), 60\% and 80\% (CA125) Table 4.

Table 1. Distribution of clinical and histological features of EOC patients, benign cysts, and healthy females.

\begin{tabular}{|c|c|c|c|}
\hline & $\begin{array}{l}\text { Malignant Lesions } \\
\mathrm{N}=30\end{array}$ & $\begin{array}{c}\text { Benign Cysts } \\
\mathrm{N}=30\end{array}$ & $\begin{array}{l}\text { Healthy Females } \\
\quad \mathrm{N}=15\end{array}$ \\
\hline \multicolumn{4}{|l|}{ Age (y) } \\
\hline Mean & 51.9 & 48.5 & 46.8 \\
\hline \multicolumn{4}{|l|}{ Parous Women } \\
\hline 0 & 4 & 11 & 5 \\
\hline 1 & 7 & 9 & 2 \\
\hline$\geq 2$ & 12 & 6 & 8 \\
\hline NA & 7 & 4 & 0 \\
\hline \multicolumn{4}{|c|}{ Menopausal Status } \\
\hline Pre & 5 & 8 & 6 \\
\hline Post & 20 & 16 & 7 \\
\hline Peri & 1 & 4 & 2 \\
\hline NA & 4 & 2 & 0 \\
\hline \multicolumn{4}{|l|}{ Histology } \\
\hline Serous & 26 & & \\
\hline Endometrioid & 4 & & \\
\hline \multicolumn{4}{|l|}{ Figo Stage } \\
\hline I & 7 & & \\
\hline II & 16 & & \\
\hline III & 7 & & \\
\hline
\end{tabular}

Table 2. Distribution of P53 codon 72 genotypes in relation to gender, location, and grade of tumour in pediatric low grade glioma cases.

\begin{tabular}{|c|c|c|c|c|c|c|c|c|}
\hline \multirow[b]{2}{*}{ Variables } & \multirow{2}{*}{$\begin{array}{l}\text { Malignant } \\
\text { Lesions }^{1} \\
(\mathrm{~N}=30)\end{array}$} & \multirow{2}{*}{$\begin{array}{c}\text { Benign } \\
\text { Cysts }^{2} \\
(\mathrm{~N}=30)\end{array}$} & \multirow{2}{*}{$\begin{array}{l}\text { Healthy } \\
\text { Females }^{3} \\
(\mathrm{~N}=15)\end{array}$} & \multirow[b]{2}{*}{$95 \% \mathrm{CI}$} & \multicolumn{2}{|c|}{ M-W } & \multicolumn{2}{|c|}{ Kruskall-Wallis $\mathrm{H}$} \\
\hline & & & & & Groups & $\begin{array}{c}\mathbf{P} \\
(Z)\end{array}$ & $\mathbf{X}^{2}$ & $\mathbf{P}$ \\
\hline \multirow{4}{*}{$\begin{array}{l}\text { Age (y) } \\
\text { Median } \\
\text { Range }\end{array}$} & \multirow{4}{*}{$\begin{array}{c}52.5 \\
(36-65)\end{array}$} & \multirow{4}{*}{$\begin{array}{c}48.5 \\
(33-63)\end{array}$} & \multirow{4}{*}{$\begin{array}{c}41 \\
(31-68)\end{array}$} & & & 0.164 & \multirow{4}{*}{2.83} & \multirow{4}{*}{0.243} \\
\hline & & & & $(48.6-55.3)^{1}$ & 1 vs 2 & $(-1.39)$ & & \\
\hline & & & & $(44.38-52.07)^{2}$ & 2 vs 3 & $\begin{array}{c}0.555 \\
(-0.59)\end{array}$ & & \\
\hline & & & & $(39.44-54.15)^{3}$ & 1 vs 3 & $\begin{array}{c}0.177 \\
(-1.35)\end{array}$ & & \\
\hline \multirow{3}{*}{$\begin{array}{c}\text { CA125 } \\
\text { (U/ml) } \\
\text { Median } \\
\text { Range }\end{array}$} & \multirow{3}{*}{$\begin{array}{c}124.5 \\
(28-746)\end{array}$} & \multirow{3}{*}{$\begin{array}{c}29.5 \\
(19-170)\end{array}$} & \multirow{3}{*}{$\begin{array}{c}27 \\
(11-35)\end{array}$} & $(99.2-241.59)^{1}$ & 1 vs 2 & $\begin{array}{l}<0.001 \\
(-4.12)\end{array}$ & \multirow{3}{*}{27} & \multirow{3}{*}{$<0.001$} \\
\hline & & & & $(30.01-62.71)^{2}$ & 2 vs 3 & $\begin{array}{c}0.063 \\
(-1.86) \\
\end{array}$ & & \\
\hline & & & & $(18.6-28.99)^{3}$ & 1 vs 3 & $\begin{array}{l}<0.001 \\
(-4.25)\end{array}$ & & \\
\hline
\end{tabular}

1,2 , and 3 refer to malignant, benign, and healthy groups, respectively. The mean difference is significant at the 0.005 level. 
Table 3. The main characteristic features of patients and the difference between groups.

\begin{tabular}{|c|c|c|c|c|c|c|c|c|}
\hline \multirow[b]{2}{*}{ Variables } & \multirow{2}{*}{$\begin{array}{c}\text { Malignant } \\
\text { Lesions }^{1} \\
(\mathrm{~N}=30)\end{array}$} & \multirow{2}{*}{$\begin{array}{l}\text { Benign } \\
\text { Cysts }^{2} \\
(\mathrm{~N}=30)\end{array}$} & \multirow{2}{*}{$\begin{array}{l}\text { Healthy } \\
\text { Females }^{3} \\
(\mathrm{~N}=15)\end{array}$} & \multicolumn{5}{|c|}{ ANOVA } \\
\hline & & & & $\mathbf{F}$ & Groups & $95 \% \mathrm{CI}$ & P-value & \\
\hline DNA Int & \multirow{3}{*}{$0.51 \pm 0.09$} & \multirow{3}{*}{$0.4 \pm 0.06$} & \multirow{3}{*}{$0.37 \pm 0.05$} & \multirow{3}{*}{21.6} & 1 vs 2 & $0.059-0.151$ & $<0.001$ & \multirow{3}{*}{$<0.001$} \\
\hline \multirow{2}{*}{ Mean $\pm S D$} & & & & & 2 vs 3 & $-0.032-0.079$ & 0.35 & \\
\hline & & & & & 1 vs 3 & $0.073-0.185$ & $<0.001$ & \\
\hline \multirow{3}{*}{$\begin{array}{c}\text { ALU115 }(\mathbf{n g} / \boldsymbol{\mu l}) \\
\text { Mean } \pm \text { SD }\end{array}$} & \multirow{3}{*}{$3.93 \pm 1.93$} & \multirow{3}{*}{$3.49 \pm 1.57$} & \multirow{3}{*}{$2.56 \pm 0.9$} & \multirow{3}{*}{3.49} & 1 vs 2 & $-0.575-1.46$ & 0.55 & \multirow{3}{*}{0.036} \\
\hline & & & & & 2 vs 3 & $-0.316-2.146$ & 0.184 & \\
\hline & & & & & 1 vs 3 & $0.128-2.59$ & 0.027 & \\
\hline \multirow{3}{*}{$\begin{array}{c}\text { ALU247 (ng/ } / \mu l) \\
\text { Mean } \pm S D\end{array}$} & \multirow{3}{*}{$2.35 \pm 1.1$} & \multirow{3}{*}{$1.69 \pm 0.66$} & \multirow{3}{*}{$1.26 \pm 0.44$} & \multirow{3}{*}{9.72} & 1 vs 2 & $0.146-1.18$ & 0.008 & \multirow{3}{*}{$<0.001$} \\
\hline & & & & & 2 vs 3 & $-0.199-1.067$ & 0.236 & \\
\hline & & & & & 1 vs 3 & $0.463-1.73$ & $<0.001$ & \\
\hline
\end{tabular}
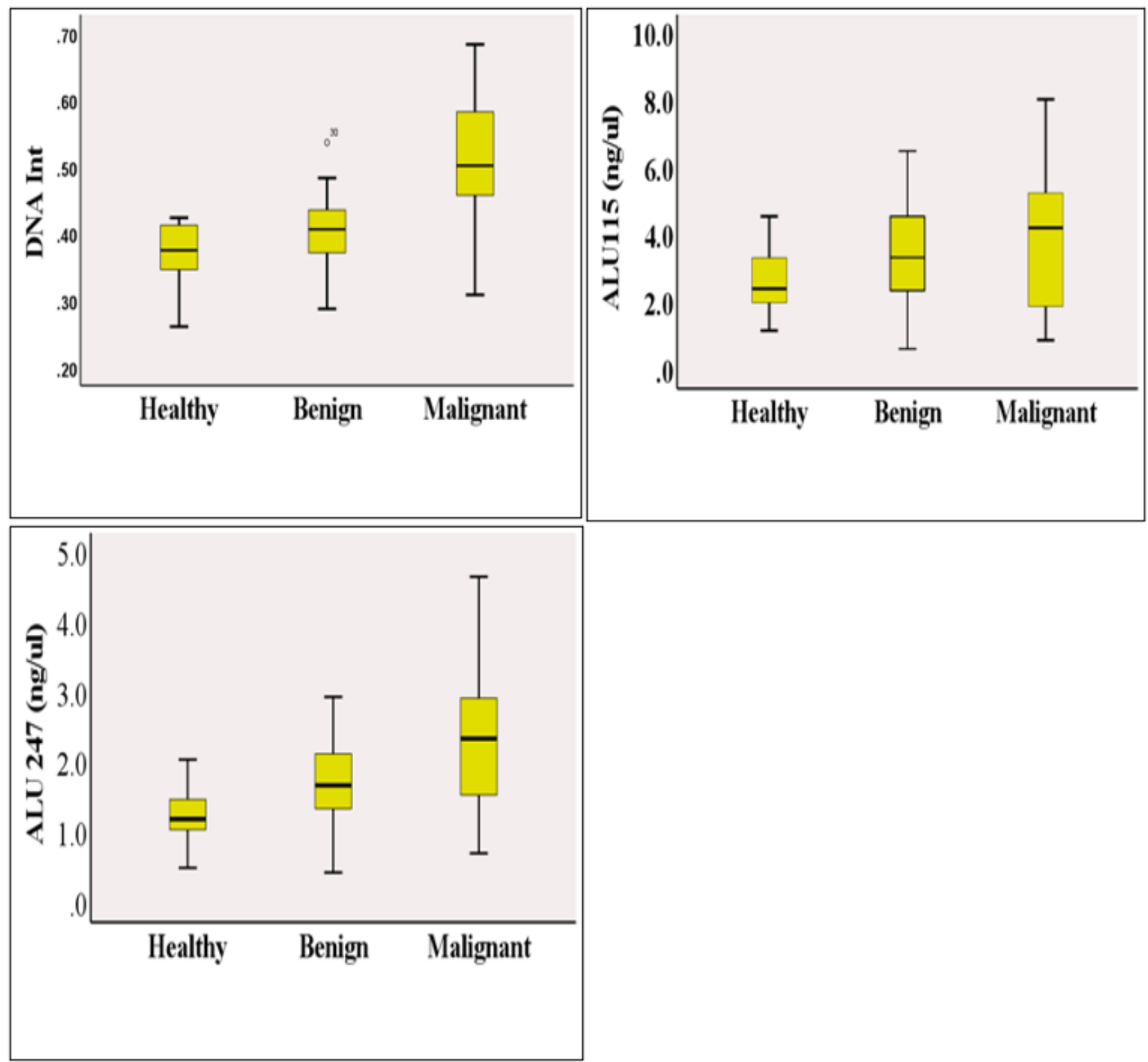

Figure 3. Value distribution of DNA Int, ALU115 and ALU247 were in three groups of healthy, benign and EOC. Bars represent the median level, boxes the interquartile range, and whiskers total ranges except outliers for patient with benign cyst. Amount of plasma DNA Integrity and ALU247 in ovarian malignant lesions were greater than benign cyst and healthy females. 


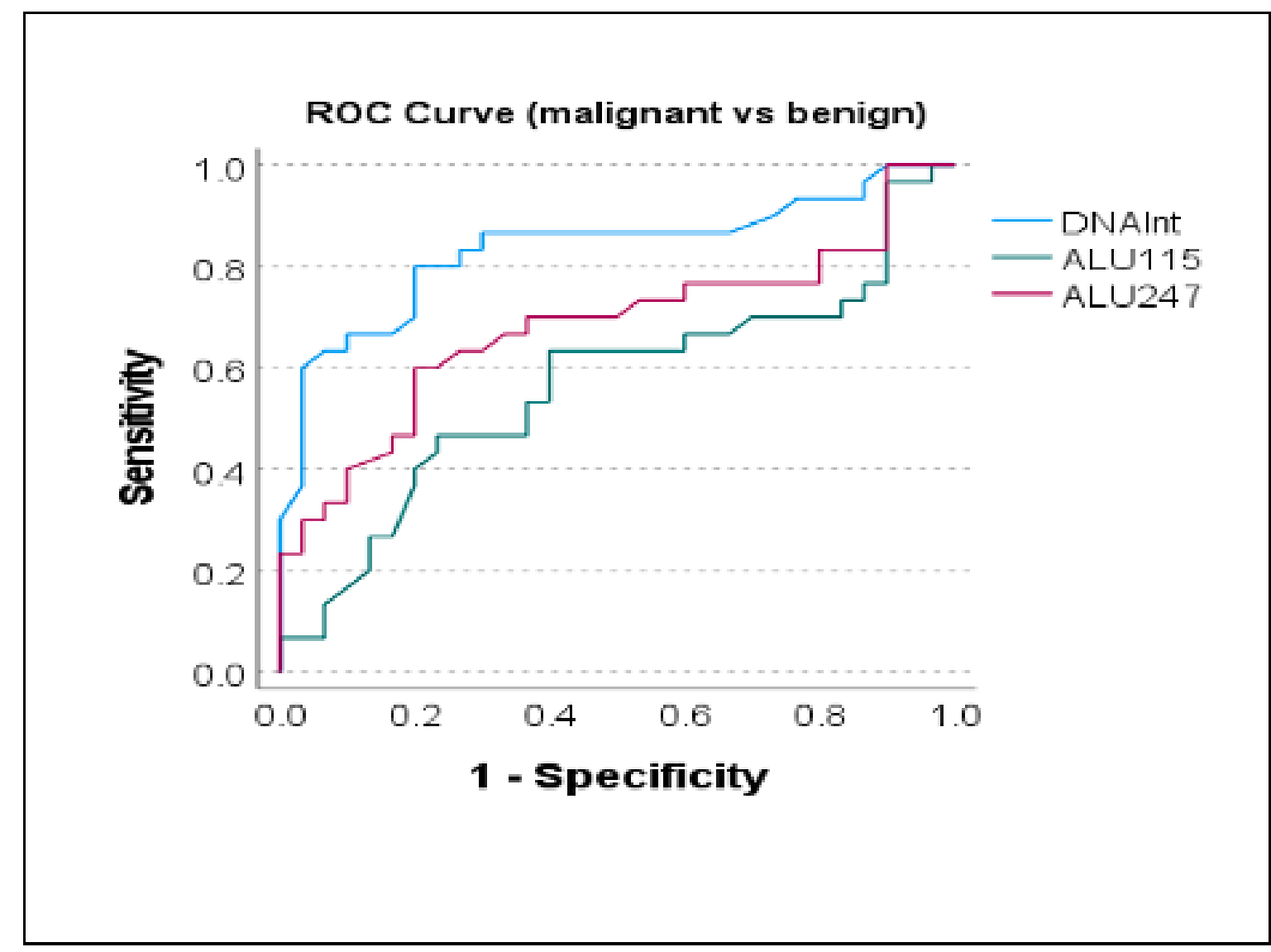

ROC Curve(malignant vs healthy)

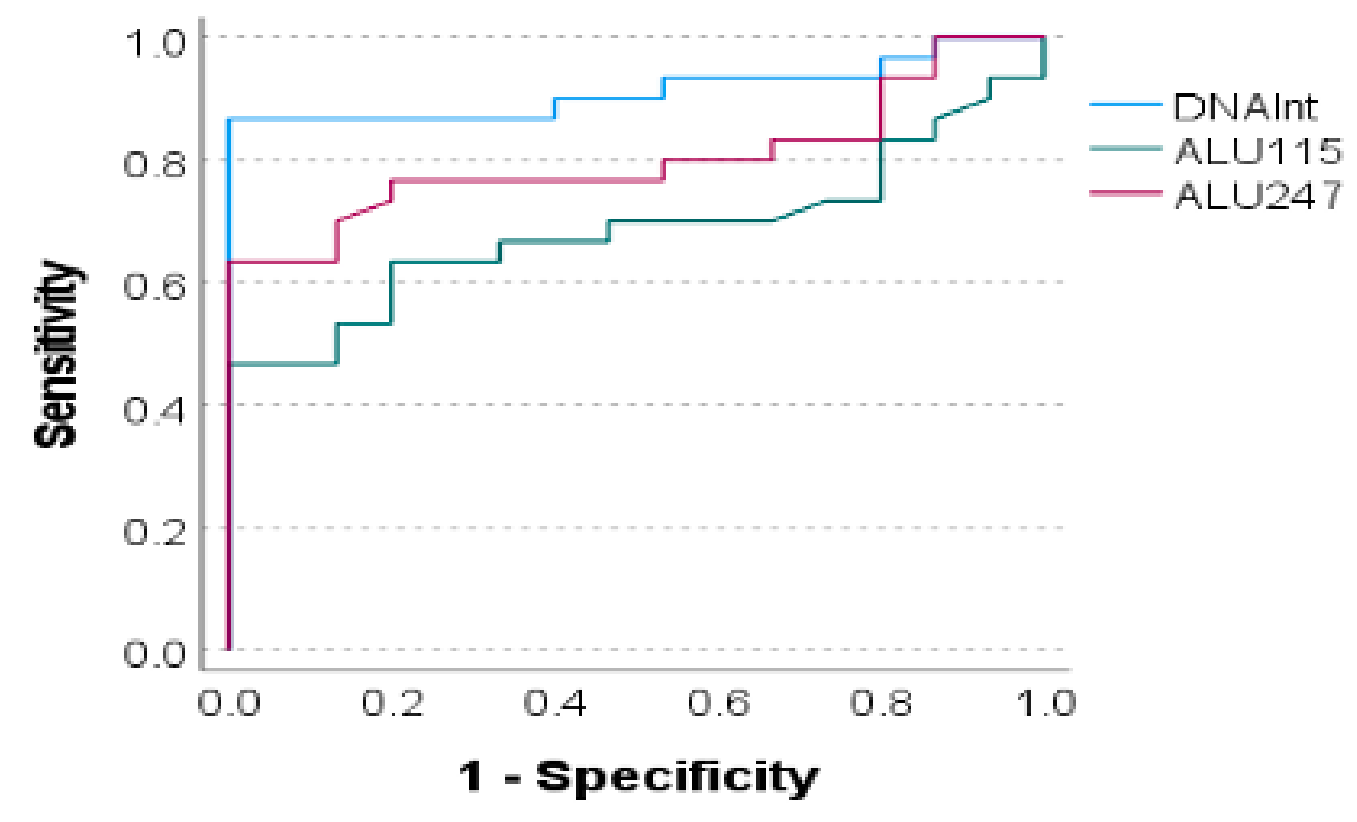

Figure 4. ROC curves of DNA Int, plasma ALU115 and ALU247 for the discrimination between primary epithelial ovarian cancer and (a) healthy females group (b) benign ovarian cyst. 
Table 4. AUC, sensitivity, specificity, and cut-off for ALU115, ALU247, and DNA Int of ovarian cancer patients vs healthy females and vs benign ovarian cysts.

\begin{tabular}{lccccc}
\hline \multicolumn{6}{c}{ EOC vs Healthy Females } \\
\hline Variables & AUC & $\mathbf{9 5 \%}$ CI & Sensitivity & Specificity & Cut off \\
DNA Int & 0.913 & $0.826-1.001$ & $86.7 \%$ & $93.3 \%$ & 0.42 \\
ALU115 & 0.696 & $0.544-0.847$ & $60.0 \%$ & $86.7 \%$ & 3.70 \\
ALU247 & 0.809 & $0.683-0.935$ & $76.7 \%$ & $86.7 \%$ & 1.52 \\
\hline \multicolumn{5}{c}{ EOC vs Benign Cysts } \\
\hline Variables & AUC & $\mathbf{9 5 \%}$ CI & Sensitivity & Specificity & Cut off \\
DNA Int & 0.834 & $0.77-0.942$ & $80.0 \%$ & $80.0 \%$ & 0.45 \\
ALU115 & 0.564 & $0.414-0.713$ & $63.3 \%$ & $60.0 \%$ & 3.60 \\
ALU247 & 0.681 & $0.541-0.820$ & $60.0 \%$ & $80.0 \%$ & 2.18 \\
\hline
\end{tabular}

\section{DISCUSSION}

The prognostic and diagnostic utility of cf-DNA -integrity in patients suffering from EOC has only been examined in a few research studies so far. Herein, cf-DNA and DNA Int were investigated on some cohorts with and without ovarian cancer to develop and validate a blood-based test for early cancer detection. Our cross-sectional study was implemented on a comparable group of preoperative untreated EOC patients.

This study reported a significant increase of DNA Int, ALU115, and ALU247 in plasma EOC patients. The total level of cf-DNA quantified as short fragment ALU115 was comparable to other previous studies that determined a high level of cf-DNA in ovarian cancer compared to healthy females (Zhang et al., 2018). Unsurprisingly, ALU115 could not distinguish patients with EOC and benign cysts diseases (P-value $>0.05)$. As benign ovarian diseases are likely accompanied by inflammation that causes an increase of cf-DNA levels in the blood as well (Kristjansdottir et al., 2014). Moreover, the AUC of ALU115 was less than 0.7 with relatively low sensitivity and specificity obtained such factors, minimize the discrimination value of ALU115 in EOC. Unlike the short fragment, long fragment ALU247 was increased in plasma of EOC patients compared to healthy and benign cysts groups with significant differences, suggesting that non-apoptotic DNA fragment might be arguably more informative in cancer detection (Stotzer et al., 2014).

No correlation was detected among ALU115, ALU247, and CA125 as assessed by Spearman correlation coefficient, often due to their distinct metabolic pathways. Notably, a previous study reported a significant decrease in the absolute level of cf-DNA in patients with OC (Holdenrieder et al., 2008; Yu et al., 2019). One explanation for this result might be due to a decline in cell death rates and instant DNA clearance.

Indeed cf-DNA is not specific for malignancy. High cf-DNA level was detected in various diseases, including stroke, trauma, cancers, pulmonary embolism, and chronic inflammatory diseases. The absence of cut-off value may limit its clinical purpose as a solo and efficient marker (Kakitsuka et al., 2020; Caglar et al., 2020; Duvvuri and Lood, 2019). Many studies observed an elevated cf-DNA concentration in different types of cancers. Zaher et al., demonstrated that the cut-off value of cf-DNA below $100 \mathrm{ng} / \mathrm{ml}$ probably represents noncancers while above $600 \mathrm{ng} / \mathrm{ml}$ probably diagnosed as cancerous tumors (Zaher et al., 2013). In 2015, Shao and his colleagues reported cf-DNA levels were 197.2, 199.9, and $811.4 \mu \mathrm{g} / \mathrm{L}$ in healthy, benign cysts and ovarian cancer groups, respectively (Shao et al., 2015). The wide variation of cf-DNA level needs further refinements.

On the other hand, DNA Int as a ratio of long (considering non-apoptotic) to short truncated DNA (representing total cellular death types) was suggested as reliable diagnostic markers for gynecological malignant tumors with poor prognosis (Labi and Erlacher, 2015). In this study, DNA Int was able to differentiate between the EOC on the one hand and the non-malignant group on the other hand. 
Recently, Zhang et al. (2018) reported findings ( $\mathrm{n}=24$ for each ovarian cancer and nonmalignant groups, AUC of DNA Int 0.759 $(95 \% \mathrm{CI}=0.619 \pm 0.898)$ and long fragment 0.73 $(95 \mathrm{CI} \%=0.581 \pm 0.879)$ the result is consistent with ours (Zhang et al., 2018). In contrast, Yu et al., (2019) noticed a high cf-DNA concentration but low DNA Int in the OC cohort than healthy volunteers ( $\mathrm{Yu}$ et al., 2019). However, the study investigated a small number of patients $(n=20$ OC group and 20 healthy controls). The direct comparison of our study with others is still complicated due to the discrepancies in sensitivity and specificity across different studies. This may be attributed to sample types (plasma or serum), different sample processing protocols, and DNA isolation methods (Trigg et al., 2018; Holdenrieder et al., 2005; Thijssen et al., 2002). Therefore, preanalytical and analytical parameters and bias in the election of the study cohort have to be taken into consideration in the analysis of results.

DNA Int was superior to the other markers in discriminating ovarian cancer, within the premise of the existing number of samples. It was ascertained that $86.6 \%$ of ovarian cancer patients with age-matched could be classified as cancerpositive compared to the control group and $80 \%$ compared to the benign group. The Further $13.5 \%$ and $20 \%$ of the EOC group had mean levels under the cut-off 0.428 and 0.451 . This might be interpreted by the inconsistency of malignant cells attitude and the rate of DNA releasing into circulation among the patients (Labi and Erlacher, 2015).

Interestingly, the discriminating ability of DNA Int was exceeding the conventional used biomarker CA125, which has a low specificity due to increased CA125 levels correlated with a variety of benign diseases (Simmons et al., 2016). Of note, CA125 was mainly elucidative for advanced and metastatic OC diagnosis but with low efficiency for early cancer identification (Stamenkovic et al., 2020).

Notably, DNA Int has values from 0 to 1 in contrast to absolute plasma cf-DNA that varies a lot. It often has values too low to be measured, suggesting that DNA Int is a better indicator for early cancer detection. DNA Int test may present a relatively modest and minimally invasive assay for cancer detection in the general population. Also, the test can be applied to other body fluids such as urine, CSF, and pleural effusions (Husain et al., 2017; Suryavanshi et al., 2020; Utting et al., 2002).

In order to develop a reliable clinical-used biomarker, the DNA Int test needs precise standardization. Our study was carefully designed to eliminate other possible variables that might affect the level of cf-DNA (Husain et al., 2017; Suryavanshi et al., 2020; Utting et al., 2002). Also, we performed two-step centrifugation during blood separation to remove cell debris. As well, the quantification of all samples was performed in a blinded and randomized manner.

Limitations of this study should also be noted. First, the sample size of the study is small due to the narrow inclusion and exclusion criteria which lead to increases in the probability of assuming as true a false premise. Meanwhile, the association of cf-DNA Int with other cell-free genes, p53 mutation, or other molecular markers didn't address in this study. Further studies into a better perception of the potency of DNA Int and ALU levels in the detection of ovarian cancer are warranted.

\section{CONCLUSION}

Plasma DNA Int and ALU274 might be clinically relevant in the assessment and diagnosis of primary EOC. The less invasive analysis of DNA Int might own the potency to supplement and substitute current tissue biopsies and CA125 in the future. Nevertheless, it would be worthwhile to investigate cf-DNA, and DNA Int combined in further prospective studies. Moreover, it seems interesting to investigate whether DNA Int can also contribute to the differentiation of various stages of EOC.

\section{CONFLICT OF INTEREST}

The authors declare no conflict of interest. 


\section{REFERENCES}

Bray, F., Ferlay, J., Soerjomataram, I., Siegel, R. L., Torre, L. A., \& Jemal, A. 2018. Global cancer statistics 2018: GLOBOCAN estimates of incidence and mortality worldwide for 36 cancers in 185 countries. CA: A Cancer Journal for Clinicians 68: 394-424.

Buys, S. S., Partridge, E., Black, A., Johnson, C. C., Lamerato, L., Isaacs, C., Reding, D. J., Greenlee, R. T., Yokochi, L. A., Kessel, B., Crawford, E. D., Church, T. R., Andriole, G. L., Weissfeld, J. L., Fouad, M. N., Chia, D., O'Brien, B., Ragard, L. R., Clapp, J. D., Rathmell, J. M., Riley, T. L., Hartge, P., Pinsky, P. F., Zhu, C. S., Izmirlian, G., Kramer, B. S., Miller, A. B., Xu, J. L., Prorok, P. C., Gohagan, J. K., Berg, C. D., \& Plco Project Team. 2011. Effect of screening on ovarian cancer mortality: The Prostate, lung, colorectal and ovarian (PLCO) cancer screening randomized controlled trial JAMA 305: 2295-303.

Caglar, O., Cilgin, B., Eroglu, M., \& Cayir, A. 2020. Evaluation of circulating cell free DNA in plasma as a biomarker of different thyroid diseases. Brazillian Journal of Otorbinolaryngol 86: 321-26.

Chiu, T. W., Young, R., Chan, L. Y., Burd, A., \& Lo, D. Y. 2006. Plasma cell-free DNA as an indicator of severity of injury in burn patients. Clinical Chemistry and Laboratory Medicine 44: 13-7.

Duvvuri, B. \& Lood, C. 2019. Cell-free DNA as a biomarker in autoimmune rheumatic diseases. Frontiers in Immunology 10: 502 .

Gasparri, M. L., Savone, D., Besharat, R. A., Farooqi, A. A., Bellati, F., Ruscito, I., Panici, P. B., \& Papadia, A. 2016. Circulating tumor cells as trigger to hematogenous spreads and potential biomarkers to predict the prognosis in ovarian cancer. Tumour Biology 37: 71-5.

Giacona, M. B., Ruben, G. C., Iczkowski, K. A., Roos, T. B., Porter, D. M., \& Sorenson, G. D. 1998. Cell-free DNA in human blood plasma: Length measurements in patients with pancreatic cancer and healthy controls. Pancreas 17: 8997.

Holdenrieder, S., Burges, A., Reich, O., Spelsberg, F. W., \& Stieber, P. 2008. DNA integrity in plasma and serum of patients with malignant and benign diseases. Annals of the New York Academy of Sciences 1137: 162-70.

Holdenrieder, S., Stieber, P., Chan, L. Y., Geiger, S., Kremer, A., Nagel, D., \& Lo, Y. M. 2005. Cell-free DNA in serum and plasma: Comparison of ELISA and quantitative PCR. Clinical Chemistry 51: 1544-6.

Husain, H., Nykin, D., Bui, N., Quan, D., Gomez, G., Woodward, B., Venkatapathy, S., Duttagupta, R., Fung, E., Lippman, S. M., \& Kurzrock, R. 2017. Cell-free DNA from ascites and pleural effusions: Molecular Insights into genomic aberrations and disease biology. Molecular Cancer Therapeutics 16: $948-55$.

Jacobs, I. J., Menon, U., Ryan, A., Gentry-Maharaj, A., Burnell, M., Kalsi, J. K., Amso, N. N., Apostolidou, S., Benjamin, E., Cruickshank, D., Crump, D. N., Davies, S. K., Dawnay, A., Dobbs, S., Fletcher, G., Ford, J., Godfrey, K., Gunu, R., Habib, M., Hallett, R., Herod, J., Jenkins, H., Karpinskyj, ., Leeson, S., Lewis, S. J., Liston, W. R., Lopes, A., Mould, T., Murdoch, J., Oram, D., Rabideau, D. J., Reynolds, K., Scott, I., Seif, M. W., Sharma, A., Singh, N., Taylor, J., Warburton, F., Widschwendter, M., Williamson, K., Woolas, R., Fallowfield, L., McGuire, A. J., Campbell, S., Parmar, M., \& Skates, S. J. 2016. Ovarian cancer screening and mortality in the UK Collaborative Trial of Ovarian Cancer Screening
(UKCTOCS): A randomised controlled trial. Lancet 387: 945-56.

Jahr, S., Hentze, H., Englisch, S., Hardt, D., Fackelmayer, F. O., Hesch, R. D., \& Knippers, R. 2001. DNA fragments in the blood plasma of cancer patients: quantitations and evidence for their origin from apoptotic and necrotic cells. Cancer Research 61: 1659-65.

Jin, Z. \& El-Deiry, W. S. 2005. Overview of cell death signaling pathways. Cancer Biology \& Therapy 4: 139-63.

Kakitsuka, Y., Sawamura, S., Kajihara, I., Kanemaru, H., Honda, N., Makino, K., Aoi, J., Makino, T., Fukushima, S., \& Ihn, H. 2020. Elevated circulating cell-free DNA levels in autoimmune bullous diseases The Journal of Dermatology 47: e345-e46.

Kristjansdottir, B., Partheen, K., Fung, E. T., Yip, C., Levan, K., \& Sundfeldt, K. 2014. Early inflammatory response in epithelial ovarian tumor cyst fluids. Cancer Medicine 3: 130212.

Labi, V. \& Erlacher, M. 2015. How cell death shapes cancer. Cell Death \& Disease 6: e1675.

Lam, N. Y., Rainer, T. H., Chan, L. Y., Joynt, G. M., \& Lo, Y. M. 2003. Time course of early and late changes in plasma DNA in trauma patients Clinical Chemistry 49: 1286-91.

Markus, H., Contente-Cuomo, T., Farooq, M., Liang, W. S., Borad, M. J., Sivakumar, S., Gollins, S., Tran, N. L., Dhruv, H. D., Berens, M. E., Bryce, A., Sekulic, A., Ribas, A., Trent, J. M., LoRusso, P. M., \& Murtaza, M. 2018. Evaluation of preanalytical factors affecting plasma DNA analysis. Scientific Reports 8: 7375.

Moss, E. L., Moran, A., Reynolds, T. M., \& Stokes-Lampard, H. 2013. Views of general practitioners on the role of CA125 in primary care to diagnose ovarian cancer. BMC Womens Health 13: 8.

Rainer, T. H., Wong, L. K., Lam, W., Yuen, E., Lam, N. Y., Metreweli, C., \& Lo, Y. M. 2003. Prognostic use of circulating plasma nucleic acid concentrations in patients with acute stroke. Clinical Chemistry 49: 562-9.

Schmalfeldt, B., Kuhn, W., Reuning, U., Pache, L., Dettmar, P., Schmitt, M., Janicke, F., Hofler, H., \& Graeff, H. 1995. Primary tumor and metastasis in ovarian cancer differ in their content of urokinase-type plasminogen activator, its receptor, and inhibitors types 1 and 2. Cancer Research 55: 3958-63.

Shao, X., He, Y., Ji, M., Chen, X., Qi, J., Shi, W., Hao, T., \& Ju, S. 2015. Quantitative analysis of cell-free DNA in ovarian cancer Oncology Letters 10: 3478-82.

Simmons, A. R., Clarke, C. H., Badgwell, D. B., Lu, Z., Sokoll, L. J., Lu, K. H., Zhang, Z., Bast Jr., R. C., \& Skates, S. J. 2016. Validation of a biomarker panel and longitudinal biomarker performance for early detection of ovarian cancer International Journal of Gynecological Cancer 26: 1070-7.

Stamenkovic, S., Cheng, J., Surowy, H., Burwinkel, B., \& Gundert, M. 2020. Circulating cell-free DNA variables as marker of ovarian cancer patients: A pilot study Cancer Biomarkers 28: $159-67$.

Stotzer, O. J., Lehner, J., Fersching-Gierlich, D., Nagel, D., \& Holdenrieder, S. 2014. Diagnostic relevance of plasma DNA and DNA integrity for breast cancer. Tumour Biology 35: 1183-91.

Suryavanshi, M., Jaipuria, J., Panigrahi, M. K., Goyal, N., Singal, R., Mehta, A., Batra, U., Doval, D. C., \& Talwar, V. 2020. CSF cell-free DNA EGFR testing using DdPCR holds promise over conventional modalities for diagnosing leptomeningeal involvement in patients with non-small cell lung cancer. Lung Cancer 148: 33-39.

Thijssen, M. A., Swinkels, D. W., Ruers, T. J., \& de Kok, J. B. 2002. Difference between free circulating plasma and serum 
DNA in patients with colorectal liver metastases. Anticancer Research 22: 421-5.

Trigg, R. M., Martinson, L. J., Parpart-Li, S., \& Shaw, J. A. 2018. Factors that influence quality and yield of circulating-free DNA: A systematic review of the methodology literature. Heliyon 4: e00699.

Umetani, N., Giuliano, A. E., Hiramatsu, S. H., Amersi, F., Nakagawa, T., Martino, S., \& Hoon, D. S. 2006. Prediction of breast tumor progression by integrity of free circulating DNA in serum. Journal of Clinical Oncology 24: 4270-6.

Utting, M., Werner, W., Dahse, R., Schubert, J., \& Junker, K. 2002. Microsatellite analysis of free tumor DNA in urine, serum, and plasma of patients: a minimally invasive method for the detection of bladder cancer. Clinical Cancer Research 8: 35-40.

Wang, B. G., Huang, H. Y., Chen, Y. C., Bristow, R. E., Kassauei, K., Cheng, C. C., Roden, R., Sokoll, L. J., Chan, D. W., \& Shih Ie, M. 2003. Increased plasma DNA integrity in cancer patients. Cancer Research 63: 3966-8.

Wang, K., Yuan, Y., Cho, J. H., McClarty, S., Baxter, D., \& Galas, D. J. 2012. Comparing the MicroRNA spectrum between serum and plasma. PLoS One 7: e41561.

Yu, Z., Qin, S., \& Wang, H. 2019. Alter circulating cell-free DNA variables in plasma of ovarian cancer patients. Journal of Obstetrics and Gynaecology Research 45: 2237-42.

Zaher, E. R., Anwar, M. M., Kohail, H. M., El-Zoghby, S. M., \& Abo-El-Eneen, M. S. 2013. Cell-free DNA concentration and integrity as a screening tool for cancer. Indian Journal of Cancer 50: 175-83.

Zhang, R., Pu, W., Zhang, S., Chen, L., Zhu, W., Xiao, L., Xing, C., \& Li, K. 2018. Clinical value of ALU concentration and integrity index for the early diagnosis of ovarian cancer: A retrospective cohort trial. PLoS One 13: e0191756.

Zhong, X. Y., Hahn, S., Kiefer, V., \& Holzgreve, W. 2007. Is the quantity of circulatory cell-free DNA in human plasma and serum samples associated with gender, age and frequency of blood donations?. Annals of Hematology 86: 139-43. 